\title{
Preparation and Study Of Zn(II) Complexes With Some Schiff Bases Derived From Acid Hydrazide- Benzil and Ethylenediamine
}

\author{
Ihsaan A. Mustafa \\ Department of Chemistry \\ College of science \\ University of Mosul
}

Received

04 / 04 / 2010

\author{
Zuhoor W. Al-Tuhafy \\ Department of Chemistry \\ College of Education \\ University of Mosul
}

Accepted

05 / 01 / 2011

\begin{abstract}
الخلاصة
ذوات الصيغة

بعض المعقدات الحلقية وغير الحلقية الجديدة

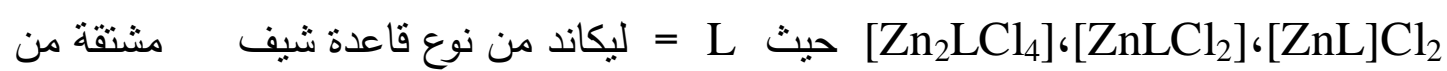
الاثثلين ثنائي الأمين مع بعض الاسترات (أثنيل ثثائي مالونيت، أثثل ثثائي سكسنيت ، أثنيل ثنائي

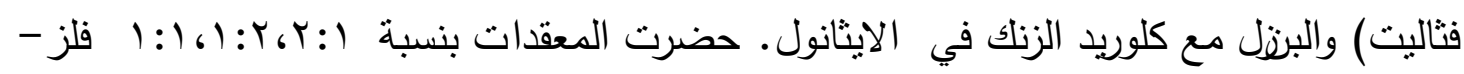

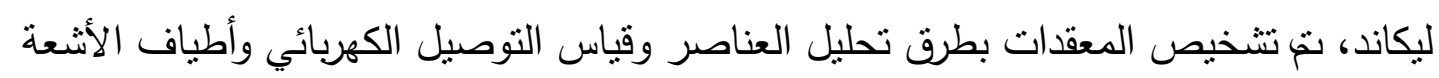

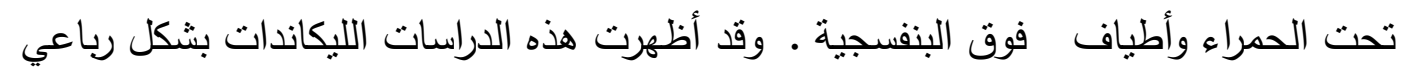

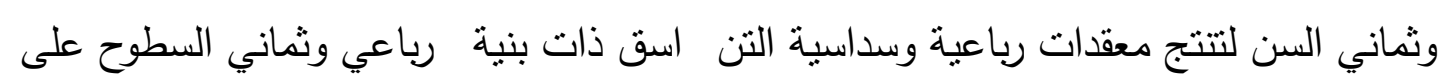
التوالي.
\end{abstract}

\begin{abstract}
Some new macrocyclic and acyclic complexes having the general formula $[\mathrm{ZnL}] \mathrm{Cl}_{2},\left[\mathrm{ZnLCl}_{2}\right],\left[\mathrm{Zn}_{2} \mathrm{LCl}_{4}\right]$ where $\mathrm{L}=$ Schiff base ligands derived from ethylene diamine with esters (diethylmalonate, diethylsuccinate and diethylphthalate) and benzil, where prepared by the reaction of zinc (II) chloride with ligands in ethanolic solution.1:1,2:1,1:2 stoichiometry of zinc (II) to ligand. Elemental analysis, molar conductance, infrared and ultraviolet studies reveal that the ligands in these complexes behave as tetra and octadentate forming tetra and hexa coordinated zinc (II) complexes respectively.
\end{abstract}




\section{Introduction}

Schiff base molecules considered as important ligands in coordination chemistry. These ligands interested many workers and several reviews and papers appeared revealing their preparation and coordination complexes $^{(1-3)}$. Schiff bases are very important from many points of view. They could be present (in addition to their solid crystal forms) as liquid crystal ${ }^{(4)}$. In coordination chemistry, they act as ligands due to their selectivity and sensitivity to the reaction with transition and non transition metal ions ${ }^{(5,6)}$. The design and synthesis of polydentate schiff bases and their properties and potential in the selective coordination of metal ions is reviewed $^{(7,8)}$. Self-condensation reaction of appropriate formyl or keto precursors with suitable polyamines can give rise to well defined planer or tridimensional macrocyclic or macroacyclic schiff bases, but different reaction path ways can also occur ${ }^{(9-11)}$. Multidentate macrocyclic ligands are cyclic molecules consisting of an organic framework interspersed with hetero atoms which are capable of interacting with a variety of species $^{(12)}$. They display unique and exciting chemistries in that they can function as receptors for substrates of widely differing physical and chemical properties and upon complexation can drastically alter these properties $^{(13)}$. For these molecules, the nature and chemical reactivity of the resulting complexes are closely associated with the ligand at framework $^{(14)}$. Considerable number of metal complexes with four and six nitrogen and oxygen donor macrocyclic ligand have been reported ${ }^{(15)}$. The biological activity of these schiff base complexes which bearing amide, azomethine and hydrazide groups is due to their action as the rapeutic agent owing to their easy hydrolysis providing low toxicity ${ }^{(16-18)}$. We are engaged in research including the synthesis of schiff base ligandsbenzolidine ethylene diamine and their new metal complexes. The research aimed also to elucidate the active site of the ligands and the possible structure and properties of the complexes.

\section{Experimental}

All reagents and solvents were of analytical grade. The ligands benzilidene ethylene diamine were prepared by the condensation of diethyl malonate, diethyl succinate or diethyl phthalate with ethylene diamine and benzil in ethanol at $25{ }^{\circ} \mathrm{C}$.

\section{Synthesis of Schiff bases:}

The Schiff bases were synthesised by the condensation of acid hydrazide and benzil (1:1),(2:1),(2:2), dissolved in ethanol. After the condensation of the solution, the precipitate was separated, filtered, washed with ethanol and dried over $\mathrm{CaCl}_{2}$ in vacuum. 


\section{Synthesis of the complexes :}

Different procedures were used for the preparation of the complexes. An ethanolic $(25 \mathrm{ml})$ solution of schiff base $(0.001 \mathrm{~mol}, 0.002 \mathrm{~mol})$ was mixed with zinc (II) chloride $(0.001 \mathrm{~mol})$ or $(0.002 \mathrm{~mol})$ ethanolic solution keeping ligand-metal ratio $1: 1,1: 2$ and 2:1. The mixture of reaction was then refluxed for $3 \mathrm{hr}$. The complexes were precipitated upon concentration of the solution and cooling in ice. The compounds separated were filtered, washed with cold ethanol and dried over $\mathrm{CaCl}_{2}$ in a vacuum. The preparation of the complexes of the types [ $\mathrm{ZnL}(\mathrm{Succ})]$ and $\left[\mathrm{Zn}_{2}(\mathrm{~L})_{2}(\mathrm{Succ}) \mathrm{Cl}_{2}\right]$ were carried out by refluxing $(0.001 \mathrm{~mol})$ and $(0.002 \mathrm{~mol})$ of $\left[\mathrm{ZnLCl}_{2}\right]$ with $(0.001 \mathrm{~mol})$ succinic acid disodium salt in ethanol-DMF for about $2 \mathrm{hrs}$. $(0.001 \mathrm{~mol})$ acetyl acetone was added to mixture of $(0.001 \mathrm{~mol})$ [ $\left.\mathrm{Zn}_{2} \mathrm{LCl}_{4}\right]$ dissolved in ethanol-DMF and refluxed for about $1.30-2 \mathrm{hrs}$ and on cooling precipitation of the complexes of both methods takes place. The separated complexes were filtered off, washed with cold ethanol and dried.

\section{Physical measurements :}

Elemental analysis were performed gravimetrically. The IR spectra of the samples were recorded using the $\mathrm{KBr}$ disc (4000-400) $\mathrm{cm}^{-1}$ FT-IR spectrophotometer. Molar conductivity were measured in freshly prepared $10^{-3}$ mol solution in DMF at room temperature with conductivity meter consort LF-42. Chlorine was determined gravimetrically as $\mathrm{AgCl}$. The UV spectra in the range (1100-200)nm range were obtained in DMF on a shmadzu UV-1650 pc spectrophotometer.

\section{Results and Discussion}

The template condensation of Schiff base ligand in the presence of zinc(II) chloride produced new metal complexes. The newly synthesized mono and binuclear Schiff base complexes are very stable at room temperature in the solid state. These chelates are generally soluble in DMF. The elemental analytical data of the complexes reveled that the compounds have a metal-ligand stoichiometry of 1:1,2:1 and 1:2. The analytical data are in good agreement with proposed stoichiometry of the complexes. The colours, melting points, IR and UV spectral data of all the compounds are presented in (Table 1-4). The conductivity values for the $\left[\mathrm{ZnL}_{3}\right] \mathrm{Cl}_{2},\left[\mathrm{ZnL}_{9}\right] \mathrm{Cl}_{2}$ complexes $\left(150,155 \mathrm{ohm}^{-1} \cdot \mathrm{cm}^{2} \cdot \mathrm{mol}^{-1}\right)$ indicate their electrolytic behaviour. This suggests that the anion $(\mathrm{Cl})$ is ionically bonded in the outer sphere of coordination. On the other hand conductivity values measured under the same conditions for the other complexes $\left(8-40 \mathrm{ohm}^{-1} . \mathrm{cm}^{2} \cdot \mathrm{mol}^{-1}\right)$ indicate that the complexes are non electrolytic in DMF solution. This suggests that the chloride ion are covalently bonded ${ }^{(19)}$. The formation of the metal-ligand bonds and the 
sites of coordination in the ligands were studied by spectral means. The IR spectra of the complexes are compared with that of the free ligand to determine the changes that might have taken place during the complexation Table(3). In the infrared spectra of the complexes, the $\mathrm{NH}_{2}$ and $\mathrm{C}=\mathrm{O}$ stretching frequencies of ethylene diamine and benzil or acetylacetone are absent with the appearance of new sharp band at 1595$1620 \mathrm{~cm}^{-1}$,characteristic of the azo methane nitrogen present in the free ligand. The lowering in this frequency region by $15-20 \mathrm{~cm}^{-1}$ indicates the condensation of carbonyl and amino groups with the involvement of the nitrogen atom of the azo methine $\boldsymbol{v}(\mathrm{C}=\mathrm{N})$ group in complex formation ${ }^{(20,21)}$. The infrared absorption spectral of the ligands show the characteristic bands at $1635-1670$ and $3310-3300 \mathrm{~cm}^{-1}$ due to $(\mathrm{C}=\mathrm{O})$ stretching and $\mathrm{NH}_{2}$ bending vibration, respectively ${ }^{(22)}$. In the spectra of complexes negative shift of about $15-32 \mathrm{~cm}^{-1}$ and $110-130 \mathrm{~cm}^{-1}$ were observed in the $(\mathrm{C}=\mathrm{O})$ stretching for cyclic (and noncyclic) complexes and $\mathrm{NH}_{2}$ bending for noncyclic complexes vibrations respectively. These negative Shifts of $(\mathrm{C}=\mathrm{O})$ and $\mathrm{NH}_{2}$ bands can be regarded as evidence for coordination through carbonyl oxygen and terminal ethylene diamine nitrogen atoms ${ }^{(23)}$. Further support for this coordination were indicated by the appearance of new bands 440-448 and $410-415 \mathrm{~cm}^{-1}$ in the infrared of the complexes are assigned to $\mathrm{M}-\mathrm{O}$ and $\mathrm{M}-\mathrm{N}$ stretching vibration, respectively ${ }^{(24)}$. The bands due to $(\mathrm{C}=\mathrm{O})$ and $\mathrm{NH}$ amide stretching vibrations located at $1635-1670$ and $3285-3297 \mathrm{~cm}^{-1}$ in the free ligands spectra were remain unaffected upon macrocyclic $\left[\mathrm{ZnLCl}_{2}\right]$ and $\left[\mathrm{ZnL} \mathrm{Cl}_{2}\right.$ complexes formation (where $\mathrm{L}=\mathrm{L}_{7}, \mathrm{~L}_{8}, \mathrm{~L}_{9}$ ) indicating the noninvolvement of carbonyl oxygen atom coordination, beside the $\mathrm{NH}$-amide vibration band remain unchanged on all complexes.

Table (1) : Some physical properties and name of the ligands

\begin{tabular}{|c|c|c|c|c|c|}
\hline No. & $\begin{array}{c}\text { Benzil } \\
\text { mol }\end{array}$ & $\begin{array}{c}\text { Acid hydrazide } \\
\text { mol }\end{array}$ & $\begin{array}{c}\text { m.p } \\
\mathrm{C}^{\mathrm{0}}\end{array}$ & Color & Name \\
\hline $\mathrm{L}_{1}$ & 0.01 & 0.01 & 190 & $\begin{array}{c}\text { Pale } \\
\text { Purple }\end{array}$ & $\begin{array}{c}\text { Benzilidine malonyl bis } \\
\text { (ethylene diamine). }\end{array}$ \\
\hline $\mathrm{L}_{2}$ & 0.01 & 0.01 & 185 & $\begin{array}{c}\text { Lemon } \\
\text { Yellow }\end{array}$ & $\begin{array}{c}\text { Benzilidine succinyl } \\
\text { bis(ethylene diamine). }\end{array}$ \\
\hline $\mathrm{L}_{3}$ & 0.01 & 0.01 & 195 & $\begin{array}{c}\text { Pale } \\
\text { yellow }\end{array}$ & $\begin{array}{c}\text { Benzilidine phthaloyl } \\
\text { bis(ethylene diamine). }\end{array}$ \\
\hline $\mathrm{L}_{4}$ & 0.01 & 0.02 & 215 & $\begin{array}{c}\text { Pale } \\
\text { Purple }\end{array}$ & $\begin{array}{c}\text { Benzilidine dimalonyl } \\
\text { tetra (ethylene diamine). }\end{array}$ \\
\hline $\mathrm{L}_{5}$ & 0.01 & 0.02 & 220 & $\begin{array}{c}\text { Pale } \\
\text { yellow }\end{array}$ & $\begin{array}{c}\text { Benzilidine disuccinyl } \\
\text { tetra (ethylene diamine). }\end{array}$ \\
\hline $\mathrm{L}_{6}$ & 0.01 & 0.02 & 235 & $\begin{array}{c}\text { Pale } \\
\text { yellow }\end{array}$ & $\begin{array}{c}\text { Benzilidine diphthaloyl } \\
\text { tetra (ethylene diamine). }\end{array}$ \\
\hline $\mathrm{L}_{7}$ & 0.02 & 0.02 & 240 & $\begin{array}{c}\text { Pale } \\
\text { Purple }\end{array}$ & $\begin{array}{c}\text { Di(benzilidine malonyl) } \\
\text { tetra(ethylene diamine). }\end{array}$ \\
\hline $\mathrm{L}_{8}$ & 0.02 & 0.02 & 248 & $\begin{array}{c}\text { Pale } \\
\text { yellow }\end{array}$ & $\begin{array}{c}\text { Di(benzilidine succinyl) } \\
\text { tetra (ethylene diamine). }\end{array}$ \\
\hline $\mathrm{L}_{9}$ & 0.02 & 0.02 & 239 & $\begin{array}{c}\text { Pale } \\
\text { yellow }\end{array}$ & $\begin{array}{c}\text { Di(benzilidine diphthaloyl) } \\
\text { tetra (ethylene diamine). }\end{array}$ \\
\hline
\end{tabular}


Table (2) : Analytical and some physical data of the complexes

\begin{tabular}{|c|c|c|c|c|c|}
\hline No. & Complex & $\begin{array}{c}\text { m.p } \\
\mathrm{C}^{\mathrm{o}}\end{array}$ & $\% \mathrm{M}$ (Calc.) & $\begin{array}{c}\Lambda_{\mathrm{m}} \text { in DMF } \\
\mathrm{ohm}^{-1} \cdot \mathrm{cm}^{2} . \\
\mathrm{mol}^{-1}\end{array}$ & $\% \mathrm{Cl}$ (Calc.) \\
\hline 1 & {$\left[\mathrm{Zn}\left(\mathrm{L}_{1}\right) \mathrm{Cl}_{2}\right]$} & 205 & $(13.12) 12.91$ & 30 & $(14.25) 14.13$ \\
\hline 2 & {$\left[\mathrm{Zn}\left(\mathrm{L}_{2}\right) \mathrm{Cl}_{2}\right]$} & 203 & $(12.76) 12.33$ & 25 & $(13.86) 13.61$ \\
\hline 3 & {$\left[\mathrm{Zn}\left(\mathrm{L}_{3}\right)\right] \mathrm{Cl}_{2}$} & 207 & $(11.67) 11.52$ & 150 & $(12.67) 12.65$ \\
\hline 4 & {$\left[\mathrm{Zn}_{2}\left(\mathrm{~L}_{4}\right) \mathrm{Cl}_{4}\right]$} & 225 & $(15.89) 15.77$ & 38 & $(17.26) 17.14$ \\
\hline 5 & {$\left[\mathrm{Zn}_{2}\left(\mathrm{~L}_{5}\right) \mathrm{Cl}_{4}\right]$} & 238 & $(15.36) 15.32$ & 18 & $(16.69) 16.35$ \\
\hline 6 & {$\left[\mathrm{Zn}_{2}\left(\mathrm{~L}_{6}\right) \mathrm{Cl}_{4}\right]$} & 252 & $(13.81) 13.61$ & 16 & $(14.99) 14.78$ \\
\hline 7 & {$\left[\mathrm{Zn}\left(\mathrm{L}_{7}\right) \mathrm{Cl}_{2}\right]$} & 255 & (7.60) 7.50 & 23 & $(8.25) 7.94$ \\
\hline 8 & {$\left[\mathrm{Zn}\left(\mathrm{L}_{8}\right) \mathrm{Cl}_{2}\right]$} & 258 & (7.36) 7.96 & 36 & (7.99)7.87 \\
\hline 9 & {$\left[\mathrm{Zn}\left(\mathrm{L}_{9}\right)\right] \mathrm{Cl}_{2}$} & 252 & (6.64) 6.52 & 155 & $(7.12) 7.10$ \\
\hline 10 & {$\left[\mathrm{Zn}\left(\mathrm{L}_{1}\right)(\mathrm{suc})\right]$} & 227 & $(12.03) 11.98$ & 10 & - \\
\hline 11 & {$\left[\mathrm{Zn}\left(\mathrm{L}_{2}\right)(\mathrm{suc})\right]$} & 260 & $(11.73) 11.71$ & 8 & - \\
\hline 12 & {$\left[\mathrm{Zn}_{2}\left(\mathrm{~L}_{1}\right)_{2}(\mathrm{suc}) \mathrm{Cl}_{2}\right]$} & 250 & $(12.55) 12.43$ & 28 & $(6.82) 6.61$ \\
\hline 13 & {$\left[\mathrm{Zn}_{2}\left(\mathrm{~L}_{2}\right)_{2}(\mathrm{suc}) \mathrm{Cl}_{2}\right]$} & 246 & $(12.22) 12.11$ & 32 & $(6.64) 6.33$ \\
\hline 14 & {$\left[\mathrm{Zn}_{2}\left(\mathrm{~L}_{10}\right) \mathrm{Cl}_{4}\right]$} & 261 & $(14.75) 13.93$ & 15 & $(16.01) 15.83$ \\
\hline 15 & {$\left[\mathrm{Zn}_{2}\left(\mathrm{~L}_{11}\right) \mathrm{Cl}_{4}\right]$} & 257 & $(14.29) 14.17$ & 40 & $(15.52) 15.41$ \\
\hline
\end{tabular}

The symmetric $(-\stackrel{\mathrm{I}}{\mathrm{C}}-\mathrm{O})$ stretching band carboxylate group shifted to lower frequency region in the spectra of complexes while the asymmetric $\left(-C^{\prime}\right)$ stretching band shifted to higher frequencies, the value of $\Delta \mathrm{v}$ about $150 \mathrm{~cm}^{-1}$, suggesting coordination of one carboxylate oxygen atom ${ }^{(25)}$. The other new band located at $570 \mathrm{~cm}^{-1}$ assigned for chloride. The shape and position of this band suggested the non-involvement of this group in coordination ${ }^{(26)}$ and therefore remain outside the coordination sphere. These observations are in agreement with the conductance data and support the given formulation of the complexes. The electronic spectra of the zinc(II) chloride complexes, in addition to the bands observed at $28571-40000 \mathrm{~cm}^{-1}$, due to $\pi \rightarrow \pi^{*}$ transitions in the free ligands, the UV spectra of the zinc(II) complexes showed additional bands in the range 28291-40122 $\mathrm{cm}^{-1}$ assigned to charge transfer transition from filled orbitals of the ligand to the vacant $\pi$ orbitals of the metal and thus supporting the formation of complexes. Sometimes the ligands are characterized by two absorption bands in the UV-region. A high intensity band and a second band with lower intensity, both bands showed red shift on coordination with metal ion. These observation represent other indication for the coordination of the ligand to the metal ion $^{(27,28)}$. The UV spectra of the complexes are summarized in Table (4).

\section{Conclusion}

$\mathrm{Zn}$ (II) is effective as a template for the Schiff base condensation of benzil-acid hydrazide with ethylene diamine ligands yielding new complexes. Zn(II) complexes have been synthesized using the Schiff base 
ligands and characterized on the basis of analytical and spectral data. The Schiff bases coordinate through azo methine nitrogens to the metal ion and act as tetra and doctadentate ligands. The complexes exhibit tetra and octahedral configuration as shown in fig (I),(II),(III)

Table(3) : The most important IR bands $\left(\mathrm{cm}^{-1}\right)$ of the ligands and their complexes

\begin{tabular}{|c|c|c|c|c|c|c|c|c|c|c|}
\hline Compound & $\begin{array}{l}\mathrm{N}-\mathrm{H} \\
\text { amide }\end{array}$ & $\begin{array}{l}\boldsymbol{v} \\
\mathrm{C}=\mathrm{O}\end{array}$ & $\begin{array}{l}\boldsymbol{v} \\
\mathrm{C}=\mathrm{N}\end{array}$ & $\mathrm{M}-\mathrm{O}$ & M-N & v $\mathrm{Cl}$ & $\begin{array}{l}\text { v } \\
\mathrm{NH}_{2}\end{array}$ & ${ }_{\text {as }}^{\mathbf{v}} \mathrm{COO}^{-}$ & $\begin{array}{l}\mathbf{v}_{\mathrm{s}} \\
\mathrm{COO}^{-}\end{array}$ & v NH \\
\hline $\mathrm{L}_{1}$ & 3295 & 1660 & 1620 & & & & & & & \\
\hline$\left[\mathrm{Zn}\left(\mathrm{L}_{1}\right) \mathrm{Cl}_{2}\right]$ & 3293 & 1640 & 1605 & 440 & 410 & & & & & \\
\hline $\mathrm{L}_{2}$ & 3294 & 1665 & 1595 & & & & & & & \\
\hline$\left[\mathrm{Zn}\left(\mathrm{L}_{2}\right) \mathrm{Cl}_{2}\right]$ & 3292 & 1633 & 1580 & 440 & 412 & & & & & \\
\hline $\mathrm{L}_{3}$ & 3285 & 1670 & 1630 & & & & & & & \\
\hline$\left[\mathrm{Zn}\left(\mathrm{L}_{3}\right)\right] \mathrm{Cl}_{2}$ & 3280 & 1655 & 1610 & 448 & 410 & 575 & & & & \\
\hline $\mathrm{L}_{4}$ & 3288 & 1650 & 1595 & & & & 3300 & & & \\
\hline$\left[\mathrm{Zn}_{2}\left(\mathrm{~L}_{4}\right) \mathrm{Cl}_{4}\right]$ & 3286 & 1630 & 1575 & 440 & 410 & & 3180 & & & \\
\hline $\mathrm{L}_{5}$ & 3297 & 1660 & 1595 & & & & 3310 & & & \\
\hline$\left[\mathrm{Zn}_{2}\left(\mathrm{~L}_{5}\right) \mathrm{Cl}_{4}\right]$ & 3295 & 1630 & 1580 & 445 & 415 & & 3200 & & & \\
\hline $\mathrm{L}_{6}$ & 3290 & 1670 & 1610 & & & & 3310 & & & \\
\hline$\left[\mathrm{Zn}_{2}\left(\mathrm{~L}_{6}\right) \mathrm{Cl}_{4}\right]$ & 3290 & 1650 & 1590 & 440 & 410 & & 3180 & & & \\
\hline $\mathrm{L}_{7}$ & 3290 & 1635 & 1595 & & & & & & & \\
\hline$\left[\mathrm{Zn}\left(\mathrm{L}_{7}\right) \mathrm{Cl}_{2}\right]$ & 3288 & 1635 & 1575 & & 410 & & & & & \\
\hline $\mathrm{L}_{8}$ & 3296 & 1641 & 1595 & & & & & & & \\
\hline$\left[\mathrm{Zn}\left(\mathrm{L}_{8}\right) \mathrm{Cl}_{2}\right]$ & 3292 & 1640 & 1575 & & 410 & & & & & \\
\hline $\mathrm{L}_{9}$ & 3290 & 1660 & 1610 & & & & & & & \\
\hline$\left[\mathrm{Zn}\left(\mathrm{L}_{9}\right)\right] \mathrm{Cl}_{2}$ & 3288 & 1658 & 1590 & & 410 & 575 & & & & \\
\hline$\left[\mathrm{Zn}\left(\mathrm{L}_{1}\right)(\mathrm{suc})\right]$ & 3290 & 1640 & 1605 & 440 & 410 & & & 1555 & 1405 & \\
\hline$\left[\mathrm{Zn}\left(\mathrm{L}_{2}\right)(\mathrm{suc})\right]$ & 3292 & 1633 & 1580 & 440 & 410 & & & 1556 & 1406 & \\
\hline$\left[\mathrm{Zn}_{2}\left(\mathrm{~L}_{1}\right)(\mathrm{suc}) \mathrm{Cl}_{2}\right]$ & 3290 & 1640 & 1605 & 440 & 410 & & & 1560 & 1410 & \\
\hline$\left[\mathrm{Zn}_{2}\left(\mathrm{~L}_{2}\right)(\mathrm{suc}) \mathrm{Cl}_{2}\right]$ & 3292 & 1633 & 1580 & 440 & 410 & & & 1558 & 1409 & \\
\hline$\left[\mathrm{Zn}_{2}\left(\mathrm{~L}_{10}\right)^{*} \mathrm{Cl}_{4}\right]$ & 3285 & 1630 & 1575 & 442 & 412 & & & & & 3185 \\
\hline$\left[\mathrm{Zn}_{2}\left(\mathrm{~L}_{11}\right)^{3+1} \mathrm{Cl}_{4}\right]$ & 3290 & 1650 & 1590 & 440 & 410 & & & & & 3190 \\
\hline
\end{tabular}

Table(4): Electronic spectral data of the complexes

\begin{tabular}{|c|c|}
\hline No. & Electronic spectra $\left(\mathrm{cm}^{-1}\right)$ \\
\hline 1 & 31846,367503 \\
\hline 2 & 32752,40007 \\
\hline 3 & 31322,32653 \\
\hline 4 & 29361,36532 \\
\hline 5 & 31665,40012 \\
\hline 6 & 28291,38313 \\
\hline 7 & 30774,36853 \\
\hline 8 & 32788,40122 \\
\hline 9 & 32171,39862 \\
\hline 10 & 27691,33662 \\
\hline 11 & 28744,37013 \\
\hline 12 & 27342,35623 \\
\hline 13 & 30451,33812 \\
\hline 14 & 27182,37355 \\
\hline 15 & 27659,35625 \\
\hline
\end{tabular}


Ihsaan A. Mustafa \& Zuhoor W. Al-Tuhafy

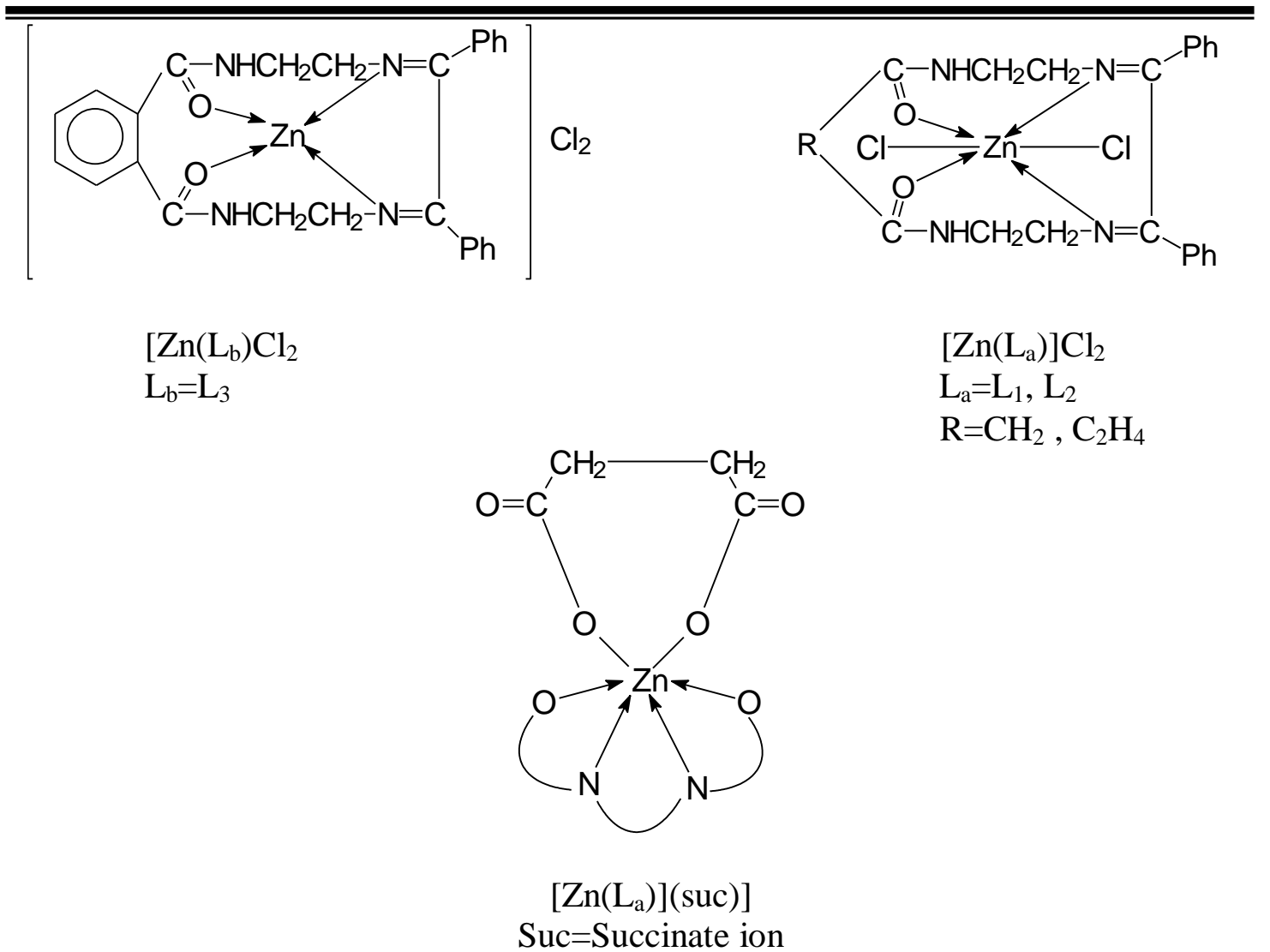

Fig (1)

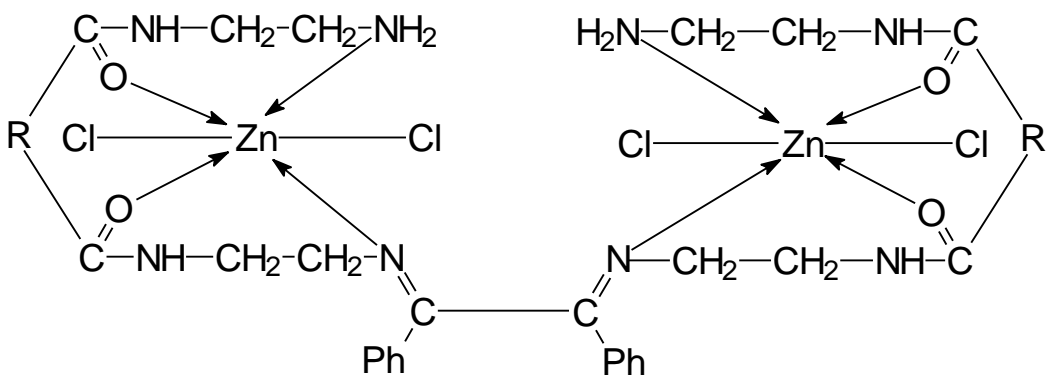

$$
\begin{gathered}
{\left[\mathrm{Zn}_{2}\left(\mathrm{~L}_{\mathrm{c}}\right) \mathrm{Cl}_{4}\right]} \\
\mathrm{L}_{\mathrm{c}}=\mathrm{L}_{4}-\mathrm{L}_{6} \\
\mathrm{R}=\mathrm{C}_{6} \mathrm{H}_{4}, \mathrm{C}_{2} \mathrm{H}_{4}, \mathrm{CH}_{2}
\end{gathered}
$$

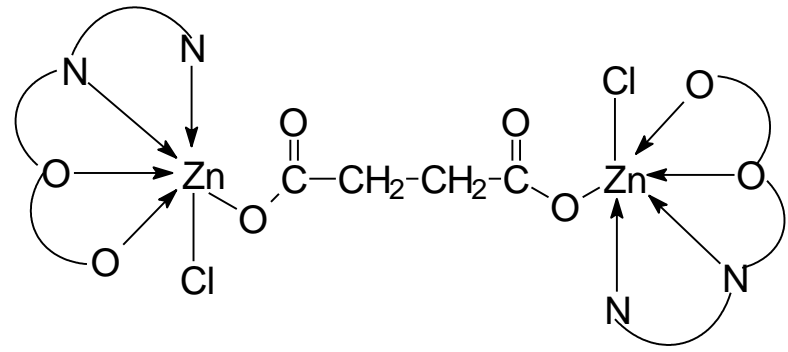

$\left[\mathrm{Zn}_{2}\left(\mathrm{~L}_{\mathrm{a}}\right)_{2}(\mathrm{Succ}) \mathrm{Cl}_{2}\right]$

Fig (II) 


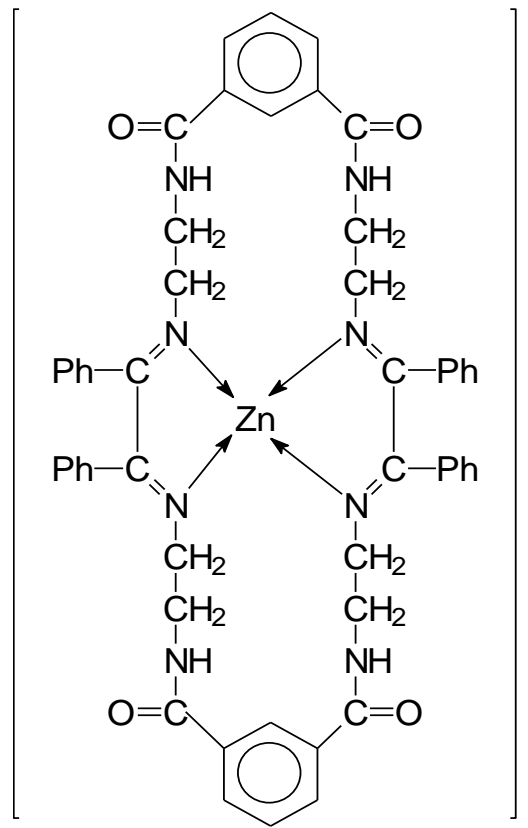

$\left[\mathrm{Zn}\left(\mathrm{L}_{\mathrm{E}}\right)\right] \mathrm{Cl}_{2}$ $\mathrm{L}_{\mathrm{E}}=\mathrm{L}_{9}$

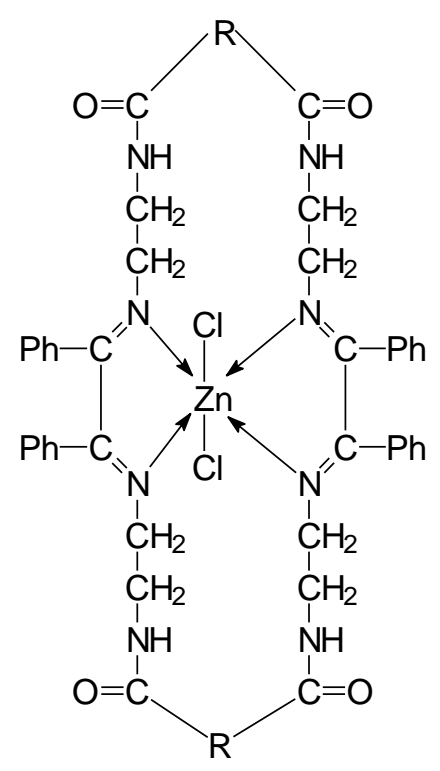

$\left[\mathrm{Zn}_{2}\left(\mathrm{~L}_{\mathrm{d}}\right) \mathrm{Cl}_{4}\right]$

$\mathrm{L}_{\mathrm{d}}=\mathrm{L}_{7}, \mathrm{~L}_{8}$

$\mathrm{R}=\mathrm{CH}_{2}, \mathrm{C}_{2} \mathrm{H}_{4}$

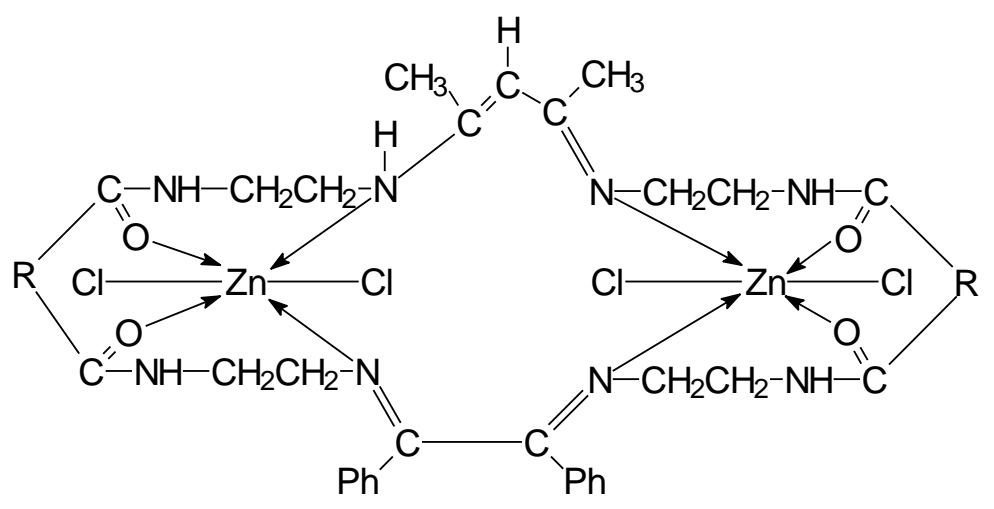

$$
\begin{gathered}
{\left[\mathrm{Zn}_{2}\left(\mathrm{~L}_{\mathrm{g}}\right) \mathrm{Cl}_{4}\right]} \\
\mathrm{L}_{\mathrm{g}}=\mathrm{L}_{10}, \mathrm{~L}_{11} \\
\mathrm{R}=\mathrm{CH}_{2}, \mathrm{C}_{2} \mathrm{H}_{4}
\end{gathered}
$$

Fig(III) 


\section{Reference:}

1) R.H. Holm and M. J.O'connor, Prog. Inorg. Chem.14,241 (1971).

2) M. C. Golonka and A. Bartecki, Coord. Chem. Rev., 31, 251 (1979).

3) I. J. Geargensen, G. Tcodoresuc and M. Zaharesu, Rev., Ran., Chim.,18, 195 (1973).

4) M. Kobayash, M. Yoshida and H. Minato, J. Org. Chem., 3583 (1971).

5) S. Yamala, Coord. Chem. Rev., 1, 415; 2,83 (1967).

6) C. K. Bhaskare and P. G. More, J. Indian. Chem. Soc., 63, 270 (1986).

7) A. Shigeki and S. Toy, Anal. chim. Acta, 274(1), 141, (1993).

8) E. Larsen, Acta. Chem. Scand., 23, 2158 (1969); 25, 962 (1971).

9) P. Guerriero, S. Tarnburin and P.A. Vigato, Coord. Chem., 139, 17243 (1995).

10) S. Larsen, Acta.Chem. Scand., 23, 2158 (1969); 25, 962 (1971).

11) S. N. Poddar and S. Ghosh, J. Indian Chem. Soc., 52, 7 (1985).

12) D. Esteban, H. Adms and D. Bariobre, Eur. J. Inorg. Chem., 1445 (2000).

13) T. Hokelek, E. E. Kaya and Kilicz., Acta Crystallogr., E57, o309 (2000).

14) J. M. Lehn, Struct. Bonding (Berlin) 1,16 (1973).

15) L. Decola, D. L. Smiles and L.M. Vallarino, Inorg. Chem., 1729 (1986).

16) M. Kitamawa, R. E. Akahane and W. M. Nakano, Chem. Abst., 112, 35803 (1990).

17) P. J. Blackburn and W. M. Chan, Biol. Med. Chem. Lett., 5(11), 11636 (1995).

18) A. A. Alexandri, G. C Safta and P. B. Bafeu, Chem. Abst., 114, 5901e (1991).

19) W. J. Gerary, Coord. Chem. Rev., 81, 7 (1971).

20) R. Karvembu, S. Hemalatha and P. akaran, Inorg. Chem. Commun., 6, 486 (2003).

21) S. Satpathy and B. Saha, J. Inorg. Nucl. Chem., 32 ,2223 (1970).

22) M. Mashima, Bull. Chem. Soc. Jpn., 35, 1882 (1962); 36, 210 (1963).

23) M. F. Iskender and L. Elsayed, J. Inorg. Nucl. Chem., 26, 551 (1974).

24) S. K. Madan and A. M. Donohus, J. Inorg. Nucl. Chem., 25, 1303 (1969).

25) M. Vidal, p. A. Vigato and V. Casello, J. Inorg. Nucl. Chem., 37, 955 (1975).

26) K. Nakamato "Infrared and Raman Spectra of Inorganic and Coordination Compounds" $5^{\text {th }}$ ed., Wiley and sons, New Yourk (1998).

27) R. K. Parihri, R. K. Patel and R. N. Patel, Oriental, J. Chem., 15, 397 (1999).

28) M. Sekerci and E. Tas, Heteroatom Chem., 11, 254 (2000). 